\title{
Genetic Variation along the Histamine Pathway in Children with Allergic versus Nonallergic Asthma
}

\author{
Sara Anvari ${ }^{1,2,3}$, Carrie A. Vyhlidal ${ }^{2,3,4}$, Hongying Dai ${ }^{2,3,5}$, and Bridgette L. Jones ${ }^{1,2,3,4}$ \\ ${ }^{1}$ Division of Allergy/Asthma/Immunology, ${ }^{4}$ Division of Pediatric Clinical Pharmacology and Therapeutic Innovation, ${ }^{5}$ Research \\ Development and Clinical Investigation, ${ }^{2}$ Children's Mercy Hospital, and ${ }^{3}$ University of Missouri Kansas City, Kansas City, Missouri
}

\begin{abstract}
Histamine is an important mediator in the pathogenesis of asthma. Variation in genes along the histamine production, response, and degradation pathway may be important in predicting response to antihistamines. We hypothesize that differences exist among singlenucleotide polymorphisms (SNPs) in genes of the histamine pathway between children with allergic versus nonallergic asthma. Children (7-18 yr of age; $n=202$ ) with asthma were classified as allergic or nonallergic based on allergy skin testing. Genotyping was performed to detect known SNPs $(n=10)$ among genes (HDC, HNMT, ABP1, $H R H 1$, and $H R H 4$ ) within the histamine pathway. Chi square tests and Cochran-Armitage Trend were used to identify associations between genetic variants and allergic or nonallergic asthma.

Significance was determined by $P<0.05$ and false-positive report probability. After correction for race differences in genotype were observed, $H R H 1-17$ TT ( $6 \%$ allergic versus $0 \%$ nonallergic; $P=0.04$ ), HNMT-464 TT (41\% allergic versus $29 \%$ nonallergic; $P=0.04$ ), and HNMT-1639 TT (30\% allergic versus $20 \%$ nonallergic; $P=0.04$ ) were overrepresented among children with allergic asthma.
\end{abstract}

Genotype differences specifically among the African-American children were also observed: HRH1-17 TT (13\% allergic versus $0 \%$ nonallergic; $P=0.04)$ and $H N M T-1639$ TT $(23 \%$ allergic versus $3 \%$ nonallergic; $P=0.03$ ) genotypes were overrepresented among African-American children with allergic asthma. Our study suggests that genetic variation within the histamine pathway may be associated with an allergic versus nonallergic asthma phenotype. Further studies are needed to determine the functional significance of identified SNPs and their impact on antihistamine response in patients with asthma and allergic disease.

Keywords: asthma; genetics; histamine

\section{Clinical Relevance}

This research highlights the potential importance of histamine in the pathogenesis of allergic asthma, especially within the understudied African-American racial group.
Asthma is a chronic inflammatory disease characterized by airway hyperresponsiveness, airflow obstruction, and variable reversibility in response to environmental exposures. According to the Centers for Disease Control and Prevention (CDC) National Asthma Surveillance Report, since 2001 the prevalence of asthma has increased by $2.9 \%$ each year from 20.3 million persons in 2001 to 25.7 million persons in 2010 (1). Asthma is also one of the most common chronic childhood diseases in developed countries; according to the 2012 National Health Interview Survey, more than 7.1 million children had an asthma diagnosis in 2011 (1).

Asthma is a complex disease for which the underlying pathophysiology is not completely understood. Several phenotypes of asthma have been identified based on underlying inflammatory mediators or triggers (2). Allergic and nonallergic asthma are common phenotypic classifications among patients with asthma. Allergic asthma is defined as asthma with allergen hypersensitivity, whereas nonallergic asthma is defined as asthma without allergen hypersensitivity. It is reported that up to $80 \%$ of patients with asthma classify as allergic asthma (3). A better understanding of the underlying pathophysiology of differing asthma phenotypes is important to improving disease evaluation and management.

Histamine (2-[4-imidazole] ethylamine) is a biogenic amine and

(Received in original form December 30, 2014; accepted in final form April 23, 2015)

This work was supported by National Heart, Lung, and Blood Institute grant 1K23HL105783.

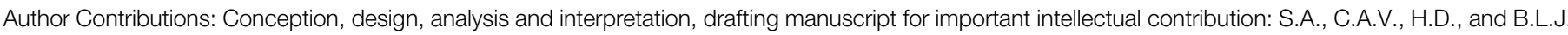

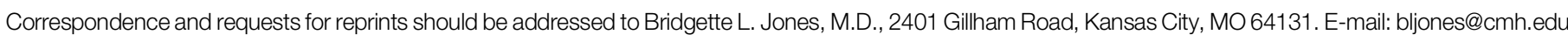
This article has an online supplement, which is accessible from this issue's table of contents at www.atsjournals.org 
Table 1. Demographic Characteristics of all Participants and among Those Classified as Allergic and Nonallergic

\begin{tabular}{|c|c|c|c|c|}
\hline Demographics & $\begin{array}{l}\text { Total Subjects } \\
(n=202)\end{array}$ & $\begin{array}{l}\text { Subjects with } \\
\text { Allergic Asthma } \\
(n=110)\end{array}$ & $\begin{array}{l}\text { Subjects with } \\
\text { Nonallergic Asthma } \\
(n=110)\end{array}$ & $P$ Value \\
\hline $\begin{array}{l}\text { Age, yr (mean } \pm \text { SD) } \\
\text { Sex, }{ }^{*} \%(n)\end{array}$ & $12.2 \pm 3.1$ & $12.6 \pm 3.1$ & $11.9 \pm 3.2$ & 0.80 \\
\hline $\begin{array}{l}\text { Male } \\
\text { Female }\end{array}$ & $\begin{array}{l}57(115) \\
43(87)\end{array}$ & $\begin{array}{l}56(65) \\
41(36)\end{array}$ & $\begin{array}{l}44(50) \\
59(51)\end{array}$ & \\
\hline $\begin{array}{l}\text { Race, }{ }^{\dagger} \%(n) \\
\text { African American }{ }^{\ddagger} \\
\text { White } \\
\text { Other }\end{array}$ & $\begin{array}{l}39(79) \\
50(101) \\
11(22)\end{array}$ & $\begin{array}{r}23(47) \\
22(44) \\
6(10)\end{array}$ & $\begin{array}{r}15(32) \\
28(57) \\
6(12)\end{array}$ & 0.16 \\
\hline
\end{tabular}

*Increased frequency of those with allergic asthma compared with those with nonallergic asthma among male subjects.

${ }^{\dagger}$ No difference in allergic versus nonallergic asthma among all racial groups combined.

\#Increased frequency of allergic asthma among African-American subjects compared with white subjects.

a known mediator in the pathogenesis of allergic rhinitis and asthma $(4,5)$. In the lungs, histamine receptor activation results in bronchospasm and airway obstruction. Plasma histamine levels have been found to correlate with asthma severity $(6,7)$, and histamine receptor activation results in increased vascular permeability, mucus production, and contraction of airway smooth muscle cells (8-11). Furthermore, targeting histamine as a therapeutic treatment has shown benefit among some patients with asthma. In one study, $\mathrm{H} 1$ antihistamines reduced respiratory symptoms and the need for rescue medications in children with allergic asthma (12). In another study, the use of antihistamines in atopic children and children considered high-risk for atopy appeared to prevent the onset of asthma when compared with placebo $(13,14)$. These data suggest that histamine plays an important role in disease pathogenesis of asthma and the therapeutic response to asthma treatments, especially among targeted phenotypes such as allergic asthma. Therefore, more research in this area is needed.

Histamine synthesis begins with the $\alpha$-decarboxylation of L-histidine by the enzyme histadine decarboxylase (HDC) $(5,15)$, and the amine exerts its effects by activating histamine receptors (HR1, HR2, HR3, and HR4) on various cells throughout the body. Histamine is degraded by two major enzymes, histamine $\mathrm{N}$-methyltransferase (HNMT) and diamine oxidase, for subsequent removal from the body $(5,9)$. Genetic variation has been observed among the genes coding for the proteins responsible for histamine production, response, and degradation (HDC, HRH1, HRH2, HRH3, HRH4, $H N M T$, and $A B P 1$ ) (5). For example, one single-nucleotide polymorphism (SNP), HNMT $314 \mathrm{C} / \mathrm{T}$, has been widely investigated in relation to asthma and allergic disease (16-21). This polymorphism results in an amino acid change (Ala138Val) and decreased enzyme activity (22). Three other SNPs have also been investigated within the pathway that also result in differences in enzyme function (ABP1 $47 \mathrm{C} / \mathrm{T}, \mathrm{ABP} 1$ $995 \mathrm{C} / \mathrm{T}$, and ABP1 $4107 \mathrm{C} / \mathrm{G})$. Although the functional significance of many identified SNPs within the pathway is unknown, several studies have been conducted to explore potential associations between histamine-related genes and asthma and allergic disease, but these studies have yielded mixed results (5, 15-26). However, previous studies have often been conducted among undefined asthma phenotypes and typically only included SNPs within single genes. In addition, we have previously reported that $H R H 1$ was more highly expressed in buccal tissue from those with asthma compared with those without asthma (27). Therefore, it is plausible that variation among genes involved in histamine production, response, and/or degradation may influence the disposition and effect of the amine within the body and effect disease pathophysiology. Identification of genetic variants related to the pharmacology of histamine may also be important to guide therapeutic treatments for histamine-related asthma phenotypes. Consequently, we conducted a pilot investigation to identify differences in genetic variants along the histamine production, response, and degradation pathway between children with allergic and nonallergic asthma.

\section{Materials and Methods}

\section{Study Population}

All study participants were enrolled in an Institutional Review Board-approved protocol after obtaining parental permission and, when appropriate (i.e., age $\geqslant 7$ yr), child assent. Convenience sampling was used for this clinic-based case-control study. Children with asthma were enrolled from Allergy, Asthma, and Immunology outpatient clinics at Children's Mercy in Kansas City, MO. Asthma was defined by $\geqslant 12 \%$ postbronchodilator reversibility in $\mathrm{FEV}_{1}$ or by an allergy/asthma specialist diagnosis based on clinical symptoms in children unable to perform spirometry. Children were classified as allergic asthma based on at least one positive skin prick test (mean wheal/flare diameter $\geqslant$ mean diameter of the positive histamine control) to at least one seasonal or perennial allergen. Subjects

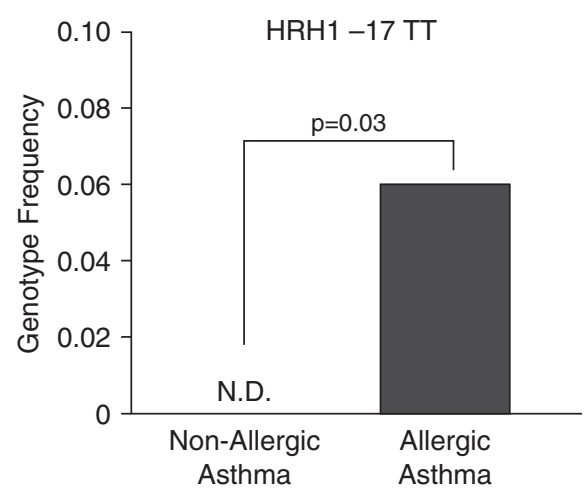

Figure 1. Differences observed in the HRH1-17 TT genotype between allergic and nonallergic asthma phenotype. The frequency of the $H R H 1-17$ variant $T$ genotype between allergic and nonallergic children differed; the homozygous variant genotype was not present in the nonallergic groups $(0.06$ allergic versus 0 nonallergic children; $P=0.03)$. N.D. indicates that the genotype was not detected in that group. 


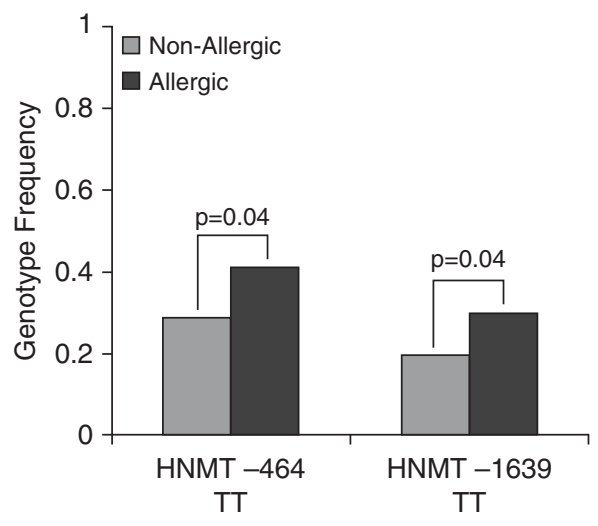

Figure 2. Differences observed in HNMT-464 and HNMT-1639 genotype frequencies between participants with allergic versus nonallergic asthma. The HNMT-464 homozygous variant $\pi$ and HNMT-1639 TT genotype frequencies differed between children with allergic and nonallergic asthma: HNMT-464 TT genotype 0.41 allergic versus 0.29 nonallergic, $P=0.04$ (after adjustment for race, $P=0.03$ ); HNMT1639 TT genotype 0.3 allergic versus 0.2 nonallergic after adjustment for race, $P=0.04$

with nonallergic asthma were defined as children with negative skin prick test to regional seasonal and perennial allergens in the past year.

\section{DNA Extraction and Genotyping}

Five milliliters of blood was collected into a glass tube containing acid citrate dextrose or calcium EDTA anticoagulant, mixed by repeated inversion, and either stored for up to 7 days at $4^{\circ} \mathrm{C}$ or immediately frozen at $-80^{\circ} \mathrm{C}$. Genomic DNA was extracted from blood using the Illustra Blood Genomic Prep Mini Spin Kit (GE Healthcare, Piscataway, NJ). Genotyping assays were performed on genomic DNA (12-16 ng) using commercially available TaqMan assays to detect the following SNPs of interest: rs1049793 (ABP1 $47 \mathrm{C} / \mathrm{T})$, rs10156191 (ABP1 $4107 \mathrm{C} / \mathrm{G}), \mathrm{rs} 1049742(A B P 1995 \mathrm{C} / \mathrm{T})$, rs17740607 (HDC $92 \mathrm{C} / \mathrm{T}), \mathrm{rs} 901865$ (HRH1-17 C/T), rs11665084 (HRH4 413 $\mathrm{C} / \mathrm{T})$, rs6430764 (HNMT-1639 C/T), rs2071048 (HNMT $464 \mathrm{C} / \mathrm{T}$ ), rs 1050900 (HNMT 3'UTR A/T), and rs 11558538 (HNMT $314 \mathrm{C} / \mathrm{T}$ ) (Applied Biosystems, Foster City, CA) and using a KAPA Probe Fast quantitative PCR master mix (Kapa Biosystems, Boston, MA) according to the manufacturer's recommendations. SNPs were chosen based on their potential functional significance and previously investigated variants (see Table E1 in the online supplement) as well as those with an expected minor allele frequency $\geqslant 2 \%$ within our expected participant population $(5,18,22,28)$. All samples were performed in duplicate to rule out random error.

\section{Statistical Analysis}

Concordance with Hardy-Weinberg equilibrium was confirmed for each SNP using available online software (29). Haplotype information was inferred using PHASE 15 software (30). Statistical analyses were performed using SAS 9.2 (SAS, Cary, NC). Chi-square tests and Student's $t$ test were used to compare demographics between allergic and nonallergic asthma groups. Chi-square tests were used to compare frequency distributions of genotype, allele, and haplotype in subjects with asthma with and without allergic sensitization. Cochran-Armitage Trend was used to test for associations between genotype frequency among allergic and nonallergic asthma. For genotype, we further performed dominant analysis (comparing homozygous wild-type + heterozygous versus non-wild-type homozygous genotypes) and recessive analysis (comparing homozygous non-wild-type + heterozygous genotype versus wild-type homozygous genotype)

Table 2. Comparison of Allele Frequencies among Studied Histamine-Related Genes between Children with Allergic versus Nonallergic Asthma

\begin{tabular}{|c|c|c|c|c|c|c|}
\hline \multirow[b]{2}{*}{ SNP (Major/Minor Allele) } & \multirow[b]{2}{*}{ Allele } & \multicolumn{2}{|c|}{ Subjects with Allergic Asthma } & \multicolumn{2}{|c|}{ Subjects with Nonallergic Asthma } & \multirow[b]{2}{*}{$P$ Value* } \\
\hline & & $n$ & $\%$ & $n$ & $\%$ & \\
\hline HDC $92 \mathrm{C} / \mathrm{T}$ & C & 14 & 7 & 21 & 10 & 0.2 \\
\hline rs 17740607 & $\mathrm{~T}$ & 188 & 93 & 181 & 90 & \\
\hline HRH1-17 C/T & C & 155 & 77 & 170 & 84 & 0.06 \\
\hline rs901865 & $\mathrm{T}$ & 47 & 23 & 32 & 16 & \\
\hline HRH4 $413 \mathrm{C} / \mathrm{T}$ & $\mathrm{C}$ & 193 & 96 & 189 & 94 & 0.4 \\
\hline rs11665085 & $\mathrm{T}$ & 9 & 4 & 13 & 6 & \\
\hline HNMT-1639 C/T & $\mathrm{C}$ & 90 & 45 & 103 & 51 & 0.2 \\
\hline rs 6430764 & $\mathrm{~T}$ & 112 & 55 & 99 & 49 & \\
\hline HNMT-464 C/T & $\mathrm{C}$ & 69 & 34 & 88 & 44 & $0.04^{\dagger}$ \\
\hline rs2071048 & $\mathrm{T}$ & 133 & 66 & 114 & 56 & \\
\hline HNMT $314 \mathrm{C} / \mathrm{T}$ & $\mathrm{C}$ & 187 & 93 & 183 & 91 & 0.5 \\
\hline rs11558538 & $\mathrm{T}$ & 15 & 7 & 19 & 9 & \\
\hline HNMT 3'UTR AVT & $A$ & 160 & 79 & 153 & 76 & 0.4 \\
\hline rs 1050900 & $\mathrm{~T}$ & 42 & 21 & 49 & 24 & \\
\hline ABP1 $47 \mathrm{C} / \mathrm{T}$ & $\mathrm{C}$ & 121 & 60 & 135 & 67 & 0.1 \\
\hline rs10156191 & $\mathrm{T}$ & 81 & 40 & 67 & 33 & \\
\hline ABP1 $995 \mathrm{C} / \mathrm{T}$ & $\mathrm{C}$ & 181 & 90 & 183 & 91 & 0.7 \\
\hline rs1049742 & $\mathrm{T}$ & 21 & 10 & 19 & 9 & \\
\hline ABP1 4107 C/G & $\mathrm{C}$ & 117 & 58 & 121 & 60 & 0.7 \\
\hline rs1049793 & $\mathrm{G}$ & 85 & 42 & 81 & 40 & \\
\hline
\end{tabular}

Definition of abbreviation: SNP, single-nucleotide polymorphism.

${ }^{\star} P$ values represent $\chi^{2} /$ Fisher's exact $P$ values for comparison of allele frequency between allergic and nonallergic asthma.

${ }^{\dagger} P$ value from the Cochran-Mantel Haenszel controlling for race effect. 
using Fisher's exact test. We performed the Cochran-Mantel-Haenszel test to compare frequencies of genotype, allele, and haplotype between allergic and nonallergic subjects, adjusted by observed confounders. Significance was determined by $P<0.05$.

Statistical significance was also determined using the False Positive Report Probability (FPRP) (31). FPRP is the probability of no true association between a genetic variant and disease given a statistically significant finding.

As a secondary exploratory analysis, we further evaluated genotype frequency according to the subgroup stratifications of race.

\section{Results}

A total of 202 children, 7 to 18 years of age, were included in this preliminary study.
Participant demographics are shown in Table 1. Allergic asthma was more common among male subjects $(P=0.03)$. AfricanAmerican children also tended to have allergic asthma rather than nonallergic asthma when compared with white children $(P=0.04)$. There were no differences in age between the two asthma phenotypes.

\section{Allele and Genotype Results}

We observed differences in genotype frequency for 3 of the 10 SNPs evaluated between subjects with allergic and nonallergic asthma. The HRH1-17 variant TT genotype was more frequent among those with allergic asthma compared with nonallergic asthma ( 0.06 allergic versus 0 nonallergic; $P=0.03$ ) (Figure 1 ). After adjusting for race, this finding was no longer significant. However, the recessive model analysis for HRH1-17 (TT versus
$\mathrm{CC}+\mathrm{CT}$ ) demonstrated modest association between the genotype and allergic asthma $(P=0.01$; after adjustment for race, $P=0.04)$. The HNMT-464 homozygous variant TT genotype was also overrepresented among those with allergic asthma compared with nonallergic asthma (0.41 allergic versus 0.29 nonallergic; $P=0.04$, and $P=0.03$ after adjustment for race) (Figure 2). The HNMT-464 T allele was also more frequent among the allergic than among the nonallergic group ( 0.66 allergic versus 0.56 nonallergic after adjustment for race; $P=0.04)$. Finally, the homozygous variant HNMT-1639 genotype (TT) was also more common among subjects with allergic asthma than among subjects with nonallergic asthma (TT $=0.3$ allergic versus TT $=0.2$ nonallergic; $P=0.04$ after adjustment for race; $P=0.02$ for recessive model analysis after race adjustment)

Table 3. Comparison of Genotype Frequencies among Studied Histamine-Related Single Nucleotide Polymorphisms in Children with Allergic versus Nonallergic Asthma

\begin{tabular}{|c|c|c|c|c|c|c|}
\hline \multirow[b]{2}{*}{ SNP } & \multirow[b]{2}{*}{ Genotype } & \multicolumn{2}{|c|}{ Subjects with Allergic Asthma } & \multicolumn{2}{|c|}{ Subjects with Nonallergic Asthma } & \multirow[b]{2}{*}{$P$ Value* } \\
\hline & & $n$ & $\%$ & $n$ & $\%$ & \\
\hline HDC $92 \mathrm{C} / \mathrm{T}$ & $\mathrm{CC}$ & 1 & 1 & 1 & 1 & 0.4 \\
\hline \multirow[t]{2}{*}{ rs 17740607} & $\mathrm{CT}$ & 12 & 12 & 19 & 19 & \\
\hline & $\mathrm{CC}$ & 88 & 87 & 81 & 80 & \\
\hline$H R H 1-17 \mathrm{C} / \mathrm{T}$ & $\mathrm{CC}$ & 60 & 59 & 69 & 68 & 0.03 \\
\hline \multirow{2}{*}{ rs901865 } & CT & 35 & 35 & 32 & 32 & \\
\hline & TT & 6 & 6 & 0 & 0 & \\
\hline $\mathrm{HRH} 4413 \mathrm{C} / \mathrm{T}$ & $\mathrm{CC}$ & 92 & 91 & 89 & 88 & 0.5 \\
\hline \multirow[t]{2}{*}{ rs11665085 } & CT & 9 & 9 & 11 & 11 & \\
\hline & $\mathrm{TT}$ & 0 & 0 & 1 & 1 & \\
\hline HNMT-1639 C/T & $\mathrm{CC}$ & 19 & 19 & 22 & 22 & $0.04^{\dagger}$ \\
\hline \multirow{2}{*}{ rs 6430764} & CT & 52 & 51 & 59 & 58 & $0.44^{\ddagger}$ \\
\hline & TT & 30 & 30 & 20 & 20 & \\
\hline HNMT-464 C/T & $\mathrm{CC}$ & 9 & 9 & 16 & 16 & $0.04^{\dagger}$ \\
\hline \multirow{2}{*}{ rs2071048 } & CT & 51 & 50 & 56 & 55 & $0.40^{\ddagger}$ \\
\hline & TT & 41 & 41 & 29 & 29 & \\
\hline HNMT $314 \mathrm{C} / \mathrm{T}$ & $\mathrm{CC}$ & 87 & 86 & 83 & 82 & 0.7 \\
\hline \multirow{2}{*}{ rs11558538 } & CT & 13 & 13 & 17 & 17 & \\
\hline & TT & 1 & 1 & 1 & 1 & \\
\hline HNMT 3'UTR AVT & $\mathrm{AA}$ & 64 & 63 & 55 & 54 & 0.3 \\
\hline \multirow{2}{*}{ rs1050900 } & AT & 35 & 32 & 43 & 43 & \\
\hline & $\mathrm{TT}$ & 5 & 5 & 3 & 3 & \\
\hline$A B P 147 \mathrm{C} / \mathrm{T}$ & $\mathrm{CC}$ & 37 & 37 & 44 & 44 & 0.3 \\
\hline \multirow{2}{*}{ rs10156191 } & CT & 47 & 46 & 47 & 47 & \\
\hline & TT & 17 & 17 & 10 & 10 & \\
\hline$A B P 1995 \mathrm{C} / \mathrm{T}$ & $\mathrm{CC}$ & 81 & 80 & 84 & 83 & 0.7 \\
\hline \multirow[t]{2}{*}{ rs1049742 } & $\mathrm{CT}$ & 19 & 19 & 15 & 15 & \\
\hline & TT & 1 & 1 & 2 & 2 & \\
\hline \multirow{3}{*}{$\begin{array}{l}\text { ABP1 } 4107 \mathrm{C} / \mathrm{G} \\
\mathrm{rs} 1049793\end{array}$} & $\mathrm{CC}$ & 33 & 33 & 40 & 40 & 0.3 \\
\hline & CG & 51 & 50 & 41 & 40 & \\
\hline & $\mathrm{GG}$ & 17 & 17 & 20 & 20 & \\
\hline
\end{tabular}

For definition of abbreviation, see Table 2.

${ }^{*} P$ value is from the $\chi^{2} /$ Fisher's exact test.

${ }^{\dagger} P$ value from the Cochran-Mantel Haenszel controlling for race effect.

${ }^{\ddagger}$ Genotype associations with asthma phenotype demonstrated false-positive report probability values $<0.5$, which is considered noteworthy for our study type per Wacholder and colleagues (31). 
Table 4. $P$ Values from Chi Square Test

\begin{tabular}{|c|c|c|c|}
\hline \multirow[b]{2}{*}{ SNP (Major/Minor Allele) } & \multicolumn{2}{|c|}{ Minor Allele/Genotype Frequency } & \multirow{2}{*}{$\begin{array}{c}P \text { Value } \\
\text { (Allele/Genotype) }\end{array}$} \\
\hline & White & African American & \\
\hline $\begin{array}{l}\text { HDC } 92 \mathrm{C} / \mathrm{T} \\
\text { rs17740607 }\end{array}$ & $0.86 / 0.74$ & $0.98 / 0.98$ & $<0.01^{*}$ \\
\hline $\begin{array}{l}\text { HRH1-17 C/T } \\
\text { rs901865 }\end{array}$ & $0.14 / 0$ & $0.27 / 0.08$ & $<0.01^{*}$ \\
\hline $\begin{array}{l}\text { HRH4 } 413 \mathrm{C} / \mathrm{T} \\
\mathrm{rs} 11665085\end{array}$ & $0.08 / \mathrm{ND}$ & $0.03 / \mathrm{ND}$ & $0.03 / \mathrm{ND}$ \\
\hline $\begin{array}{l}\text { HNMT-1639 } \mathrm{C} / \mathrm{T} \\
\text { rs } 6430764\end{array}$ & $0.57 / 0.31$ & $0.43 / 0.15$ & $0.01 / 0.02$ \\
\hline $\begin{array}{l}\text { HNMT } 314 \mathrm{C} / \mathrm{T} \\
\mathrm{rs} 11558538\end{array}$ & $0.13 / 0.02$ & $0.01 / \mathrm{ND}$ & $<0.01^{*}$ \\
\hline $\begin{array}{l}\text { HNMT 3'UTR A/T } \\
\text { rs1050900 }\end{array}$ & $0.27 / \mathrm{ND}$ & $0.18 / \mathrm{ND}$ & $0.04 / N D$ \\
\hline $\begin{array}{l}A B P 147 \mathrm{C} / \mathrm{T} \\
\text { rs10156191 }\end{array}$ & $0.29 / 0.10$ & $0.46 / 0.18$ & $<0.01^{\star}$ \\
\hline $\begin{array}{l}A B P 14107 \mathrm{C} / \mathrm{G} \\
\text { rs1049793 }\end{array}$ & $0.29 / 0.12$ & $0.52 / 0.27$ & $<0.01^{*}$ \\
\hline
\end{tabular}

Definition of abbreviations: ND, no difference in genotype frequency between white and AfricanAmerican subjects; SNP, single-nucleotide polymorphism.

${ }^{\star} P$ values for allele and genotype comparisons between white and African-American subjects are both $<0.01$

(Figure 2). There were no significant differences observed for allele or genotype for the other SNPs evaluated (Tables 2 and 3 ).

To prevent false-positive discoveries and to adjust for multiple testing, we calculated the FPRP for significant SNPs identified in Table 4 (31). According to Wacholder and colleagues (31), we consider our study as a small initial study and chose a FPRP value $<0.5$ to be noteworthy. Assuming a prior probability of association of 0.4 and an odds ratio of true association of 2, the FPRP for HNMT $1639 \mathrm{C} / \mathrm{T}$ rs6430764 was 0.11 and for HNMT $464 \mathrm{C} / \mathrm{T}$ rs2071048 was 0.09 . These results are supportive of an association of genetic variants in HNMT with allergic asthma.

\section{Secondary Analysis between Racial Groups}

Analysis by race. Genetic differences relative to race were observed among several SNPs (Table 4).

Analysis of allele and genotype frequencies in subjects with allergic versus nonallergic asthma within racial subgroups. Recognizing that disease phenotype and pathophysiology differ between races, we performed further exploratory analyses to evaluate allele and genotype frequencies within the specified racial groups of
"African American" and "white" by allergic and nonallergic asthma phenotype. Similar to results in the entire cohort, AfricanAmerican subjects with allergic asthma more commonly possessed the variant homozygous genotype for HRH1-17 (TT = $0.13)$ than those with nonallergic asthma (TT $=0 ; P=0.04$ and $P=0.04$ from recessive genotype model analysis) (Figure 3A). The HNMT-1639 TT genotype was also more frequent among AfricanAmerican subjects with allergic asthma than nonallergic asthma ( $\mathrm{TT}=0.23$ allergic asthma versus TT $=0.03$ nonallergic asthma; $P=0.03$ and $P=0.02$ for recessive genotype model analysis) (Figure $3 \mathrm{~A}$ ). Finally, we observed an increased frequency of one SNP, ABP1 $4107 \mathrm{C} / \mathrm{G}$, among white children with nonallergic asthma. The ABP1 4107 GG genotype was more frequent among the nonallergic children than among the allergic children $(0.18$ nonallergic versus 0.05 allergic; $P=0.04$ for both genotype and recessive model genotype analyses) (Figure 3B).

\section{Haplotype Results}

Fifteen different haplotypes were observed in our cohort that differed among white and African-American subjects (Tables 5 and 6). There was no association between asthma phenotype and haplotype for any of the observed haplotypes within the entire cohort or within stratified racial groups.

\section{Discussion}

Histamine-related genes may be important in the pathogenesis of asthma. We observed an association between genetic variants of two genes within the histamine pathway, HRH1 and HNMT, and the allergic asthma phenotype in our cohort of children. We also observed novel, and potentially important, associations between histamine gene variants, race, and asthma phenotype. Here we report that HRH1-17 TT and HNMT-1639 TT genotypes were associated with the allergic asthma phenotype among African-American children and that the ABP 4107 GG genotype was associated with nonallergic asthma among white children. This is the first study to our knowledge to describe a relationship between histamine pathway genes and allergic asthma among a phenotypically well-defined cohort. Our study provides more evidence that histamine indeed plays a significant role in asthma pathogenesis, especially within the allergic asthma phenotype. Previous investigations have yielded mixed results regarding the relationship between histamine-related genes and asthma $(16,18-21,23-26,32)$. We believe that our study underscores the importance of conducting asthma-related genetic studies within cohorts of well-defined asthma phenotypes and also among diverse racial and ethnic groups. African Americans, who bear significant morbidity and mortality associated with asthma, are a particularly understudied racial group among genetic studies of asthma (33). Previous studies of histamine pathway genes have included very low numbers of African Americans or none at all $(16,18-21,23-26,32)$.

Genome-wide association studies have been conducted to determine differences in genetic makeup between allergic and nonallergic asthma. One large, genomewide association study identified SNPs associated with atopic asthma (34), and a genetic risk score based on these identified SNPs was developed that further confirmed an association between these gene variants and asthma (35). However, none of the histamine-related SNPs was identified to be associated with asthma (atopic or nonatopic) in these two studies. In contrast to our study, the genetic association study by Moffat and colleagues (34) evaluated atopy with total IgE levels versus positive skin prick testing, which we 
A

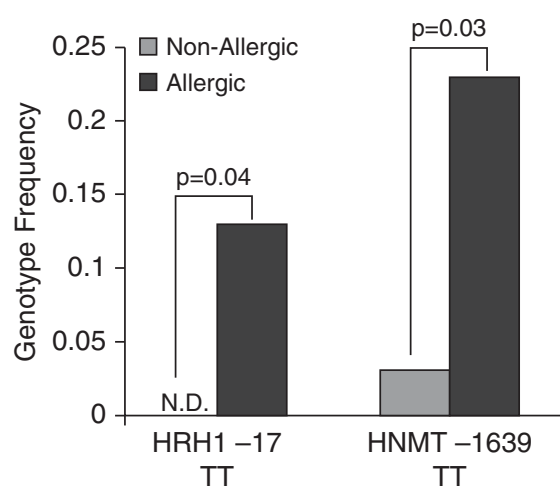

B

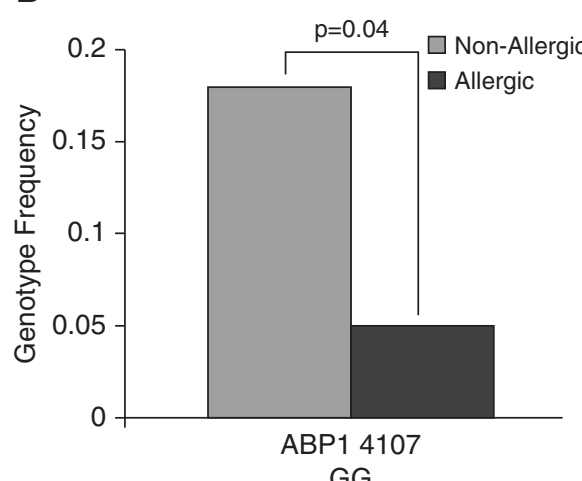

Figure 3. Differences in genotype frequencies relative to asthma phenotype among stratified African-American and white children. (A) AfricanAmerican subjects with allergic asthma more commonly possessed the variant homozygous genotype for $\mathrm{HRH1}-17(\mathrm{TT}=0.13)$ than those with nonallergic asthma $(T=0)(P=0.04 ; P=0.04$ from recessive genotype model analysis). The HNMT-1639 TT genotype was more frequent among African-American subjects with allergic asthma than nonallergic asthma $(T T=$ 0.23 allergic asthma versus $\Pi=0.03$ nonallergic asthma; $P=0.03$ and $P=0.02$ for recessive genotype model analysis). N.D. indicates that the genotype was not detected in that group. $(B)$ In white children the ABP1 4107 GG genotype frequency differed between allergic and nonallergic participants $(0.18$ nonallergic versus 0.05 allergic; $P=0.04$ for both genotype and recessive model genotype analyses).

used in this study. In addition, the cohorts in these studies differed from ours because they included primarily participants of European descent. We identified 4 of the 10 SNPs that we evaluated among the GABRIEL Consortium genome-wide association study and found that none of the four SNPs was associated with asthma compared with control subjects in this large cohort comprised largely of European participants. Our results presented here suggest that perhaps histamine-related genes are more important among some racial groups than others. Therefore, it is essential that relationships between genetics and disease are identified among diverse populations so as to provide medical knowledge that will lead to improved diagnostic and therapeutic treatments among differing racial and ethnic groups.

In contrast to our findings, Sasaki and colleagues (18) did not observe an association between HRH1-17 C/T (or HRH $2543 \mathrm{G} / \mathrm{A}$ and HNMT $314 \mathrm{C} / \mathrm{T}$ ) and allergic asthma in 100 Japanese children. The lack of an association between HRH1$17 \mathrm{C} / \mathrm{T}$ SNP and allergic asthma in their study may have been due to a poorly defined allergic asthma phenotype because they used only an elevated IgE level as a criterion for allergic asthma. Differences in the racial makeup of their study must also be considered because previously identified SNPs were not detected in their cohort, likely due to differences in the racial makeup between their cohort and previously studied groups as well as our cohort. In our study, the HRH1-17 variant $\mathrm{T}$ allele was more common among AfricanAmerican children than among white children and was also more common among African-American subjects with allergic asthma compared with those with nonallergic asthma. Our findings suggest that the HRH1-17 SNP may be of particular importance in the pathogenesis of allergic asthma, especially among the AfricanAmerican population.

Several conflicting studies, predominantly conducted in cohorts of white subjects, exist regarding the relationship between the commonly investigated HNMT $314 \mathrm{C} / \mathrm{T}$ SNP and asthma $(20,21,26)$. In our study, we did not find an association between HNMT 314 and asthma phenotype. However, we did find two novel associations between HNMT SNPs, HNMT-464 and HNMT1639 , and allergic asthma. The HNMT1639 SNP was also specifically relevant within the African-American cohort in relation to asthma phenotype. Although the functional relevance of these noncoding SNPs is currently unclear, our findings suggest that further investigations should include these variants because they may be linked with SNPs that result in protein changes or, given their position relative to the HNMT gene, may affect levels of expression. Investigation of single SNPs may not adequately predict disease association and may also lead to conflicting results among studies. Future studies should include haplotype investigations among the histamine-related genes to more clearly elucidate the role of these genes in disease.

We also identified one SNP, $A B P 14107$ $\mathrm{C} / \mathrm{G}$, that was related to asthma phenotype among white children. This SNP, along with another variant $(A B P 147 \mathrm{C} / \mathrm{T})$, has been shown to result in altered diamine oxidase enzyme activity $(4,23)$. In addition, Maintz and colleagues (32) observed that the $A B P 147 \mathrm{~T}$ allele was associated with "histamine intolerance," defined as headache and flushing when consuming histamine-rich substances. These findings suggest that variants within $A B P 1$ may be related to the function of diamine oxidase activity, which may be clinically important in disease phenotypes that involve histamine (e.g., allergic asthma). Previous studies including white subjects have not

Table 5. Observed ABP1 Haplotypes and Frequencies among the Entire Cohort

\begin{tabular}{|c|c|c|c|c|c|}
\hline Haplotype & $A B P 147 \mathrm{C} / \mathrm{T}$ & $A B P 1995 \mathrm{C} / \mathrm{T}$ & ABP1 $4107 \mathrm{C} / \mathrm{G}$ & $\%(n)^{*}$ & $\begin{array}{c}\text { Racial } \\
\text { Differences }^{\dagger}\end{array}$ \\
\hline 1 & C & C & G & $18(73)$ & Both \\
\hline 2 & C & C & $\mathrm{G}$ & 45 (182) & Both \\
\hline 3 & C & $\mathrm{T}$ & $\mathrm{T}$ & $0.5(1)$ & White \\
\hline 4 & $\mathrm{~T}$ & C & G & $13(54)$ & Both \\
\hline 5 & $\mathrm{~T}$ & C & $\tilde{C}$ & $14(55)$ & Both \\
\hline 6 & $\mathrm{~T}$ & $\mathrm{~T}$ & $\mathrm{~T}$ & $9(38)$ & Both \\
\hline 7 & $\mathrm{~T}$ & $\mathrm{~T}$ & G & $0.5(1)$ & Other \\
\hline
\end{tabular}

*Number of haplotypes observed.

†Describes whether haplotype is present only in African-American subjects, only in white subjects, both, or other racial group. 
Table 6. Observed HNMT Haplotypes and Frequencies among the Entire Cohort

\begin{tabular}{|c|c|c|c|c|c|c|}
\hline Haplotype & $\begin{array}{c}H N M T-1639 \\
\text { C/T }\end{array}$ & $\begin{array}{c}H N M T-464 \\
\text { C/T }\end{array}$ & $\begin{array}{c}\text { HNMT } \\
314 \mathrm{C} / \mathrm{T}\end{array}$ & $\begin{array}{c}\text { HNMT } \\
\text { 3'UTR A/T }\end{array}$ & $\%(n)^{*}$ & $\begin{array}{c}\text { Racial } \\
\text { Differences }\end{array}$ \\
\hline 1 & $\mathrm{~T}$ & $\mathrm{~T}$ & C & A & 49 (197) & Both \\
\hline 2 & $\mathrm{~T}$ & $\mathrm{~T}$ & C & $\mathrm{T}$ & $3(11)$ & Both \\
\hline 3 & $\mathrm{~T}$ & $\mathrm{~T}$ & T & $\mathrm{T}$ & 1 (3) & White \\
\hline 4 & $\mathrm{C}$ & $\mathrm{T}$ & C & A & $6(23)$ & African American \\
\hline 5 & C & $\mathrm{T}$ & C & $\mathrm{T}$ & $3(13)$ & Both \\
\hline 6 & C & C & C & A & 23 (93) & Both \\
\hline 7 & C & $\mathrm{C}$ & C & $\mathrm{T}$ & $8(33)$ & Both \\
\hline 8 & C & $\mathrm{C}$ & $\mathrm{T}$ & $\mathrm{T}$ & 7 (31) & Both \\
\hline
\end{tabular}

${ }^{*}$ Number of haplotypes observed.

${ }^{\dagger}$ Describes whether haplotype is present only in African-American subjects, only in white subjects, or both.

reported an association between $A B P 1$ genetic variation and asthma $(20,21)$.

The most significant limitations of our study were the small sample size and the limited sample size for analyses conducted among racial groups. Racial heterogeneity among our cohort is a limitation, and further studies should focus on larger, racially homogeneous populations given the known differences in inheritance and linkage disequilibrium between racial groups. We believe that our findings among the African-American participants deserve more investigation given the differences in genotype frequency observed between the allergic and nonallergic groups in this racial group. We also recognize that SNPs identified to be associated with allergic asthma are in noncoding regions and therefore may only be "tagging" SNPs for other gene regions that may have functional significance. However, we believe that gene regions that may affect gene expression should also be explored. Further work is needed to determine the potential functional significance of these SNPs and to identify other more functionally relevant SNPs that may be in linkage.
We believe that our findings are important in further understanding the pathophysiology of asthma among different patient populations. With validation, this information may be useful in using genotype in predicting therapeutic response to antihistamines for the treatment of asthma because those with altered histamine production, degradation, or receptor function may respond differently to antihistamines. Future studies are needed to confirm our results in a larger cohort of participants with allergic asthma, specifically focusing on potentially relevant and understudied subgroups (e.g., AfricanAmerican subjects). In addition, further studies are required to determine the functional significance of identified SNPs and their impact on disease phenotype as well as the inclusion of other potentially important histaminerelated genes (HRH2 and $\mathrm{HRH} 3$ ) and haplotypes. Our study supports revisiting the role of histamine in asthma and the role of antihistamine treatment for those with well-defined asthma phenotypes.

Author disclosures are available with the text of this article at www.atsjournals.org.

\section{References}

1. National Heart, Lung, and Blood Institute. Expert Panel Report 3 (EPR3): Guidelines for the diagnosis and management of asthma 2007. 2007 [updated 2012 Apr; accessed 2014 Mar 1]. Available from: http://www. nhlbi.nih.gov/guidelines/asthma/asthgdln.htm.

2. Barnes PJ. Pathophysiology of allergic inflammation. Immunol Rev 2011; 242:31-50.

3. Bourdin A, Gras D, Vachier I, Chanez P. Upper airway $x$ 1: allergic rhinitis and asthma: united disease through epithelial cells. Thorax 2009;64: 999-1004.

4. Maintz L, Novak N. Histamine and histamine intolerance. Am J Clin Nutr 2007;85:1185-1196.

5. García-Martín E, Ayuso P, Martínez C, Blanca M, Agúndez JA. Histamine pharmacogenomics. Pharmacogenomics 2009;10:867-883.

6. Busse WW, Swenson CA. The relationship between plasma histamine concentrations and bronchial obstruction to antigen challenge in allergic rhinitis. J Allergy Clin Immunol 1989;84:658-666.

7. Simon RA, Stevenson DD, Arroyave CM, Tan EM. The relationship of plasma histamine to the activity of bronchial asthma. J Allergy Clin Immunol 1977;60:312-316.

8. O'Byrne PM, Inman MD. Airway hyperresponsiveness. Chest 2003;123 (Suppl):411S-416S.

9. Jones BL, Kearns GL. Histamine: new thoughts about a familiar mediator. Clin Pharmacol Ther 2011;89:189-197.

10. Schmelz M, Schmidt R, Bickel A, Handwerker HO, Torebjörk HE. Specific C-receptors for itch in human skin. J Neurosci 1997;17: 8003-8008.

11. Clough GF, Bennett AR, Church MK. Effects of $\mathrm{H} 1$ antagonists on the cutaneous vascular response to histamine and bradykinin: a study using scanning laser Doppler imaging. Br J Dermatol 1998;138:806-814.
12. Grant JA, Nicodemus CF, Findlay SR, Glovsky MM, Grossman J, Kaiser $\mathrm{H}$, Meltzer EO, Mitchell DQ, Pearlman D, Selner J, et al. Cetirizine in patients with seasonal rhinitis and concomitant asthma: prospective, randomized, placebo-controlled trial. J Allergy Clin Immunol 1995; 95:923-932.

13. Bustos GJ, Bustos D, Bustos GJ, Romero O. Prevention of asthma with ketotifen in preasthmatic children: a three-year follow-up study. Clin Exp Allergy 1995;25:568-573.

14. Warner JO; ETAC Study Group. Early Treatment of the Atopic Child. A double-blinded, randomized, placebo-controlled trial of cetirizine in preventing the onset of asthma in children with atopic dermatitis: 18 months' treatment and 18 months' posttreatment follow-up. J Allergy Clin Immunol 2001;108:929-937.

15. Hirata N, Takeuchi K, Ukai K, Sakakura Y. Expression of histidine decarboxylase messenger RNA and histamine $\mathrm{N}$-methyltransferase messenger RNA in nasal allergy. Clin Exp Allergy 1999;29:76-83.

16. García-Martín E, García-Menaya J, Sánchez B, Martínez C, Rosendo R, Agúndez JA. Polymorphisms of histamine-metabolizing enzymes and clinical manifestations of asthma and allergic rhinitis. Clin Exp Allergy 2007;37:1175-1182.

17. Kennedy MJ, Loehle JA, Griffin AR, Doll MA, Kearns GL, Sullivan JE, Hein DW. Association of the histamine N-methyltransferase C314T (Thr105lle) polymorphism with atopic dermatitis in Caucasian children. Pharmacotherapy 2008;28:1495-1501.

18. Sasaki Y, Ihara K, Ahmed S, Yamawaki K, Kusuhara K, Nakayama H, Nishima S, Hara T. Lack of association between atopic asthma and polymorphisms of the histamine $\mathrm{H} 1$ receptor, histamine $\mathrm{H} 2$ receptor, and histamine N-methyltransferase genes. Immunogenetics 2000; $51: 238-240$.

19. Sharma S, Mann D, Singh TP, Ghosh B. Lack of association of histamine-N-methyltransferase (HNMT) polymorphisms with asthma in the Indian population. $J$ Hum Genet 2005;50:611-617. 
20. Szczepankiewicz A, Bręborowicz A, Sobkowiak P, Popiel A. Polymorphisms of two histamine-metabolizing enzymes genes and childhood allergic asthma: a case control study. Clin Mol Allergy 2010;8:14.

21. Yan L, Galinsky RE, Bernstein JA, Liggett SB, Weinshilboum RM. Histamine $\mathrm{N}$-methyltransferase pharmacogenetics: association of a common functional polymorphism with asthma. Pharmacogenetics 2000;10:261-266.

22. Preuss CV, Wood TC, Szumlanski CL, Raftogianis RB, Otterness DM, Girard B, Scott MC, Weinshilboum RM. Human histamine $\mathrm{N}$-methyltransferase pharmacogenetics: common genetic polymorphisms that alter activity. Mol Pharmacol 1998;53: 708-717.

23. Ayuso P, García-Martín E, Martínez C, Agúndez JA. Genetic variability of human diamine oxidase: occurrence of three nonsynonymous polymorphisms and study of their effect on serum enzyme activity. Pharmacogenet Genomics 2007;17:687-693.

24. Deindl P, Peri-Jerkan S, Deichmann K, Niggemann B, Lau S, Sommerfeld C, Sengler C, Müller S, Wahn U, Nickel R, et al.; German Multicenter Atopy Study Group. No association of histamine$\mathrm{N}$-methyltransferase polymorphism with asthma or bronchial hyperresponsiveness in two German pediatric populations. Pediatr Allergy Immunol 2005;16:40-42.

25. Gervasini G, Agúndez JA, García-Menaya J, Martínez C, Cordobés C, Ayuso P, Cornejo JA, Blanca M, García-Martín E. Variability of the L-histidine decarboxylase gene in allergic rhinitis. Allergy 2010;65: 1576-1584.

26. Simon T, Semsei AF, Ungvári I, Hadadi E, Virág V, Nagy A, Vangor MS, László V, Szalai C, Falus A. Asthma endophenotypes and polymorphisms in the histamine receptor $\mathrm{HRH} 4$ gene. Int Arch Allergy Immunol 2012;159:109-120.
27. Vyhlidal CA, Riffel AK, Dai H, Rosenwasser LJ, Jones BL. Detecting gene expression in buccal mucosa in subjects with asthma versus subjects without asthma. Pediatr Allergy Immunol 2013;24:138-143.

28. Hon YY, Jusko WJ, Zhou HH, Chen GL, Guo D, Zhou G, Spratlin VE, Jann MW. Endogenous histamine and cortisol levels in subjects with different histamine N-methyltransferase C314T genotypes: a pilot study. Mol Diagn Ther 2006;10:109-114.

29. Santiago Rodriguez TRGalNMD. Hardy-Weinberg equilibrium testing of biological ascertainment for mendelian randomization studies. 2008 [accessed 2014 Jan 15]. Available from: http://www.oege.org/ software/hwe-mr-calc.shtml.

30. Stephens M, Smith NJ, Donnelly P. A new statistical method for haplotype reconstruction from population data. Am J Hum Genet 2001;68:978-989.

31. Wacholder S, Chanock S, Garcia-Closas M, El Ghormli L, Rothman N. Assessing the probability that a positive report is false: an approach for molecular epidemiology studies. J Natl Cancer Inst 2004;96:434-442.

32. Maintz L, Yu CF, Rodríguez E, Baurecht H, Bieber T, Illig T, Weidinger $\mathrm{S}$, Novak N. Association of single nucleotide polymorphisms in the diamine oxidase gene with diamine oxidase serum activities. Allergy 2011;66:893-902.

33. Scirica CV, Celedón JC. Genetics of asthma: potential implications for reducing asthma disparities. Chest 2007;132(Suppl):770S-781S

34. Moffatt MF, Kabesch M, Liang L, Dixon AL, Strachan D, Heath S, Depner M, von Berg A, Bufe A, Rietschel E, et al. Genetic variants regulating ORMDL3 expression contribute to the risk of childhood asthma. Nature 2007;448:470-473.

35. Belsky DW, Sears MR, Hancox RJ, Harrington H, Houts R, Moffitt TE, Sugden K, Williams B, Poulton R, Caspi A. Polygenic risk and the development and course of asthma: an analysis of data from a fourdecade longitudinal study. Lancet Respir Med 2013;1:453-461. 